\title{
Consequences of Economic Deconcentration in Italy and Rome: Unplanned Processes in a Highly Regulated Country
}

\author{
Armando Montanari and Barbara Staniscia \\ Dipartimento di Studi Europei, Americani e Interculturali, Sapienza Università di Roma, Piazzale Aldo Moro 5, 00185 Roma, Italy \\ Correspondence should be addressed to Armando Montanari, armando.montanari@uniroma1.it
}

Received 10 January 2012; Revised 6 March 2012; Accepted 18 April 2012

Academic Editor: Robert C. Kloosterman

Copyright (C) 2012 A. Montanari and B. Staniscia. This is an open access article distributed under the Creative Commons Attribution License, which permits unrestricted use, distribution, and reproduction in any medium, provided the original work is properly cited.

\begin{abstract}
This paper analyses the relationship between deconcentration processes, planning policies, and governance in the metropolitan area of Rome, Italy, from 1991 to 2001. It points out that Rome does not have an explicit policy either in favor of or against deconcentration and that the public authorities are not in fact aware of the problem. Deconcentration is mainly driven by market forces and business location decisions. These decisions are strongly influenced by material factors such as accessibility, land availability, and real estate prices, as well as immaterial factors such as the natural, cultural, and social environment. Public players can take action to influence these factors. Even though Italy has a very strictly regulated planning system, there has traditionally been a high degree of freedom in actual behaviors.
\end{abstract}

\section{Introduction}

This paper deals with the economic deconcentration that took place in Rome in the 1991 to 2001 period and its relation to planning policies and the Italian governance system. The paper is organized as follows. The first part details the concept of economic deconcentration and previous studies on the subject and illustrates the research methodology. It subsequently analyzes urban policies in Italy and identifies and analyzes national, regional, subregional, and local policies relevant to deconcentration. The paper then focuses on the implications of deconcentration for Rome.

Economic deconcentration can be defined as the movement of economic activity from cores towards suburbs in metropolitan areas. It can be measured through the relative changes in the number of jobs and companies for each economic sector and each subarea over a given period of time. The issue of economic deconcentration has been examined within the European project SELMA: Spatial Deconcentration of Economic Land Use and Quality of Life in European Metropolitan Areas (http://selma.rtdproject.net/). The SELMA project-in which the authors of this paper were involved - was carried out by universities and research institutes in Italy, the Czech Republic, Denmark, Israel, The
Netherlands, Spain, and the UK. SELMA analyzed the nature and extent of employment deconcentration in fourteen metropolitan areas in Europe (the phenomenon had previously been studied in the 1990s in several American metropolitan regions). Economic and residential deconcentration processes interact and are likely to contribute to the phenomenon of sprawl, which has varying economic, social, and environmental effects depending on the situation of each urban settlement. Sprawl has been extensively studied in Europe and North America, as it is often the result of a demand for low-density housing connected to the autonomy and convenience provided by individual car ownership.

The SELMA project took two main factors into consideration to measure employment deconcentration: the size of the phenomenon and its growth in relation to urban forms. These two factors were considered separately for different economic activities driving the deconcentration process. The pattern of deconcentration-whether scattered or polycentric — was also determined. The phenomenon witnessed in American and European metropolitan areas is the result of similar processes but possibly different forces: in the US, the process of deconcentration is due to very weak regulatory instruments, while, in Europe, the phenomenon is more compact because it is far more strictly regulated [1]. 
The SELMA project's analysis of deconcentration was based on subdividing metropolitan areas into concentric zones, from the centre to the periphery: the core of the CBD (or central city), the rest of the central city, and the inner suburban and outer suburban rings.

The most obvious result of deconcentration processes in European cities is the proliferation in suburban areas of factories and warehouses as well as hypermarkets, malls, office complexes, and entertainment centers. European cities have been described as "cities circled by a bacon ribbon-a belt of wealthy communes: wealthy because of the high-standing equipment with retail trade, industrial sites or education and health infrastructure. New installations in the sectors of trade, industry, research, education and leisure even look for more peripheral locations in areas which until recently could be characterized as totally rural" [2].

The characteristics of the deconcentration process in the metropolitan area of Rome have already been documented [3-5]: it is of small scale and scattered because of feeble job growth and the continuing attraction of the city centre for many tertiary sector businesses. Nevertheless, how did the process take place? What role have the planning authorities played, and how did the private sector influence the process through its choices of location?

The conceptual outline provided by Razin [6] makes it possible to identify four different types of deconcentration in Europe: (i) a highly regulated Continental-Northern European type, (ii) a slightly less regulated British type, (iii) a Southern European type, where lower levels of regulation and enforcement could be expected, and (iv) a postcommunist Central European type, characterized by lower standards of living and by either low levels of regulation and enforcement or antagonism towards central planning. According to the pattern drawn up by Larsen [7] and the model further developed by Dijst and Vazquez [8], Italy can be classified, in the European context, as leaning "towards a decentralized liberal system model" (p. 267) [8]. Italy is, in fact, a country with a high level of decentralization where, despite the high level of regulation, there is a high degree of freedom in actual practice.

The results of the SELMA research show that types of governance systems have a decisive impact on economic deconcentration. The systems in Mediterranean European countries, postcommunist Europe, and Israel are a far cry from the US, a prototype of a decentralized liberal state. This is particularly evident when the results are compared with those of northern European countries, which show a pattern of autonomous local planning which is strongly influenced by market-based players [7].

The analyses drawn up within the SELMA project and the results presented in this paper refer to the 1991-2001 period. This is because the statistical data needed for an international comparison are only recorded by national censuses. The last complete ones available for Italy date back to 2001. The latest census (2011) is still underway. Less detailed data supplied by other sources has, however, made it possible to identify a slowdown of the phenomenon, for two main reasons: (i) an increased market focus on residential deconcentration in the first part of the 2000-2010 decade; (ii) a decrease in construction activity in the second half of the decade as a result of the economic crisis.

\section{Methodology}

Previous studies have shown that Italy does not have an explicit deconcentration policy [5]. As a result, there are no documents dealing specifically with the problem of deconcentration. For the purposes of this study, we have therefore reviewed documents relating to land use and planning at the regional, provincial, and municipal levels. Following the documentary review, we interviewed "key persons": 23 representatives of local authorities and businesses whose jobs and responsibilities allow them to provide interesting insight into the issue of deconcentration. The public officials interviewed are representatives of the Rome municipality, while the private-sector interviewees work in audiovisual, ICT, and retail (hypermarkets) companies located within the Rome municipality. The choice was made based on the following considerations. Quantitative analysis of the phenomenon [5] revealed that, in all the economic sectors, deconcentration mainly took place in the area between the core and the rest of the central city, particularly in the vicinity of a key piece of infrastructure: the ring road. It was also found that deconcentration has not taken place in the outer ring of the Rome metropolitan area and that the phenomenon remains marginal in the inner ring compared to the core and the rest of the central city, despite a significant trend towards an increased number of jobs. In the Rome metropolitan area two municipalities comprise the core and the central city: Rome and Fiumicino (which was part of the Rome municipality up until the early 1990s). All these elements were taken into account in the choice of the interviewees.

\section{Urban Policies in Italy}

A report by the Italian Ministry of Infrastructure and Transport, which is in charge of national planning policy, points out "the lack of an integrated plan for interventions based on a clearly defined program" in a report on urban policy in Italy, specifying that "another reason is the fragmentation of responsibility for intervention in urban areas among the various levels of government" [9]. Faludi and Waterhout [10] comment that traditional urban planning in Italy "places the emphasis on local planning and design"; as a result, "Italy does not have national spatial planning." The EU Compendium on Italy [11] concludes that "territorial planning is practically non-existent at the national level, merely a guideline at the regional level, and implemented at the local level," adding that the government "is only responsible for deciding the general direction of planning, and for coordination. In particular, it prepares guidelines for the layout of the national territory." Therefore, "there is no official territorial re-organization strategy to refer to at the national government level."

Urban policies in Italy are implicit and of a mostly infrastructural nature. Major public works have been implemented, particularly in the transport and mobility sectors. 
Projects aimed at solving environmental and social problems such as unemployment and environmental degradation have been included within policies concerning specific economic sectors, or macroareas such as Southern Italy.

In general, projects have been implemented in a fragmented, occasional, and limited way-examples are the projects undertaken in specific cities for major events such as the 1990 football World Cup, the 1994 G7 summit in Naples, and the Jubilee 2000 in Rome. "There has so far been an almost total lack of any significant attempt to implement, or at least plan, an integrated strategy that, alongside the interventions in infrastructures (public works), promotes interventions in the services sector in order to foster employment and economic activity" [9]. It can be legitimately said that there is a "lack of a true national policy able to develop an articulated strategy of intervention in the rundown urban areas" [9] where action is vital. Such deficiencies and failures have been compensated by particularly dynamic action at the local level, stimulated by new planning laws. We will examine these further on.

One factor that has had an indirect but significant influence on urban planning policy is the passing of laws to protect and enhance the environment, starting with the Landscape Protection Act known as the Galasso Law (8 August 1985, n. 431), followed by several other laws setting up national parks, regional parks, and protected areas. These policies have been positively influenced by EU environmental guidelines. The Rome municipality, for example, has implemented a number of Agenda 21 activities and passed a regional law to create natural reservoirs extending over more than two-thirds of the municipality's total surface area.

While that was happening at the national level, local planning policies changed over the same period and started adopting the methods of participation and negotiation. Local governments, represented mainly by mayors, have turned entrepreneurial. They forge alliances with other stakeholders in the territory and often create development agencies working with local banks, financial institutions, insurance companies, and associations to decide and implement plans to develop and renovate urban districts, thereby kicking off a process of governance.

Such new urban planning policies are characterized by an approach of the "local development" type [12]; the approach is used as a conceptual reference and operating principle. Three big "issues" of international significance and one "typically Italian issue" have contributed to the affirmation of this approach in Italy. (i) The environmental issue: it is understood that the problems of the natural environment can no longer be tackled per se, they have to be tackled in a integrated way; (ii) the development issue: no longer merely economic efficiency, but also social equity and quality of life; (iii) the role of the third stakeholder: inclusion of civil society together with the government and the market; (iv) the inadequacy of the City Master Plan in solving the problems of complex systems.

These new needs led, during the 1990s, to a social construct of the plan with the following characteristics [13]: (i) its purpose is the growth of the community; (ii) its specific objective is integrated development; (iii) its action method is interaction among all the stakeholders involved, through participatory policies covering a specific territorial area and its inhabitants; (iv) its identity model is no longer the social class, but the local community; (v) it involves an expert technician whose role is to activate interaction among the stakeholders.

These new needs have also led to environmental planning, or what could be defined as the environmental construction of the plan - a plan that goes beyond the antinomy of protected areas to be preserved versus nonprotected areas to be exploited. The characteristics of this approach are [13] (i) no longer only protected areas/non-protected areas, but global environmental requalification; (ii) no longer protection against the local communities, but protection in alliance with the local communities; (iii) conservation as a basis for innovation.

Finally, these new needs have led to what could be defined as an economic construct of the plan. The traditional plan as per Law 1150 of 1942 envisaged planning as a precondition for decisions regarding the localization of economic activity and residential buildings. The plan was decided in an authoritative way by the public authorities. The new plan, on the other hand, takes the economic requirements of companies into account and therefore recognizes the need for greater freedom of activity in the territory, with the aim of guaranteeing freedom of economic initiative.

Many tools other than the City Master Plan are used at the local level to correct or make up for what is lacking in the Plan. These tools are also consistent with the new rationale of participation and shared choices.

According to Governa and Salone [14, 15], Palermo [16], and Rivolin [17], there are two types of planning programs in Italy, managed by the Ministry of Infrastructure and Transport and the Ministry of Economy and Finance, respectively. The first type, managed by the Ministry of Infrastructure and Transport, are known as Complex Urban Programs. These include (i) the PRU (Programmi di Recupero Urbano, or Urban Recovery Programs), introduced by Legislative Decree n. 398/1993 and by Article 11 of the law dated 4 December 1993); (ii) the PRIU (Programmi di Riqualificazione Urbana, or Urban Regeneration Programs), introduced by a decree of the Ministry of Public Works dated 21 December 1994); the Contratti di Quartiere, or Neighborhood Contracts, set out by Article 2 of Law 662/96 and by a decree of the Ministry of Public Works dated 22 October 1997, and Neighborhood II set out by Law 21/2001; the PRUSST (Programmi di Recupero Urbano e di Sviluppo Sostenibile del Territorio, or Urban Regeneration and Sustainable Territory Development Programs) introduced by Ministerial Decree n. 1169 dated 8 October 1998 and Ministerial Decree n. 170 dated 28 May 1999. These tools are used in addition to and often as an exception to what is envisaged in the City Master Plan and the Plan of Territorial Coordination, the aim being to coordinate the actions of different municipalities and speed up procedures.

Governa and Salone [18] state that these tools are inspired by the following principles: (i) intersectorial and multidimensional action that takes not only the urban and territorial aspects, but also the economic and social spheres into 
account; (ii) coordinated action by the various institutional stakeholders; (iii) cooperation between public and privatesector stakeholders. In particular, PRUSST envisages territorial and urban participation in sustainable local development and action targeted to developing the territory, with the private sector contributing at least a third of the total budget.

The second type of planning program, managed by the Ministry of Economy and Finance, is known as Negotiated Programming (Law 662/1996 and the CIPE resolution dated 21 March 1997). This comprises (i) Patti Territoriali, or Territorial Pacts; (ii) Contratti d'area, or Area Contracts; (iii) Contratti di Programma, or Program Contracts; (iv) Accordi di programma quadro, or Program Framework Agreements; (v) Intese istituzionali di programma, or Institutional Program Agreements. In addition to these tools, there is the PIT (Programmi Integrati Territoriali, or Territorial Integrated Programs), introduced in 1999 and targeted at coordinating local development actions, linking national actions to EU actions and enhancing the integration of the objectives and strategies of the tools used.

This set of tools was created, in particular, as a fresh mode of action in the marginal and depressed areas of Southern Italy following the failure of the extraordinary intervention. These programs are based on the new rationale (new for Italy in the early 1990s, i.e.) of the bottom-up approach, the partnership method, and the use of endogenous resources for development. Their priority is therefore the development of marginal and depressed areas and, as a logical consequence, intervention in the field of planning, particularly as regards Territorial Pacts and Area Contracts.

Governa and Salone [14] provide an interesting outline that identifies the key objectives, the stakeholders involved, and the territorial contexts for the most important instruments listed. In addition to the City Master Plan municipalities can adopt the Integrated Programs of Intervention, which were introduced by Article 16 of Law 179 of 1992 to correct and amend the obvious deficiencies of the City Master Plan. They can be used, in particular, to manage urban empty spaces created by the emptying out of densely populated cities. The program is not affected by the content of the City Master Plan, and can even modify its recommendations. The program is put into action in obsolete or degraded areas that are the result of a previous process of urbanization and comprises demolitions, reconstructions, reconversions, and new constructions, followed by the setting up of basic infrastructure and road connections. The program envisages the necessary participation of many stakeholders: municipalities, public authorities, enterprises, banks, and landowners. The combined participation envisages the use of public and private-sector financial resources and makes these resources immediately operational. The Integrated Programs of Intervention do not set out a prescription; however, they comprise a global plan for the involved area. This tool proves that the lawmakers' interest has moved from territorial planning to economic and occupational development, so much so that the Integrated Programs of Intervention can create exceptions to the prescriptions of the City Master Plan following the obtention of an agreement among the partners.

\section{Profile of Policies Relevant to Deconcentration in the Italian Context}

As has already been pointed out, Italy has no specific policies to either favor or discourage economic deconcentration. What does exist is a set of problematic issues that, once tackled, have indirect effects on deconcentration. The following issues appear important.

(i) In cities with problems of industrial decline or delayed development, local urban development policies have been put in place. Those policies tend to attract investment, particularly from the private sector, that can bring in a new and highly specialized workforce through the creation of research centers and by hosting the headquarters of multinationals and national and international organizations. The new population deriving from this attraction has a high cultural level and high levels of consumption, allowing these towns to progress in the direction of the knowledge and information society. These new arrivals or, at any rate, the need to attract new arrivals have caused, or can theoretically cause, deconcentration effects. For example, recovery and regeneration actions have been implemented in the suburbs of Turin and Milan, which have suffered industrial decline. The aim is to create suitable spaces for firms in the advanced tertiary and leisure sectors to substitute old and obsolete industrial infrastructure. This process has also taken place in southern Italian cities such as Naples. The phenomenon is less obvious in the metropolitan areas this paper focuses on: Rome and Pescara-Chieti. This is because, in the first case, the city has not experienced either industrial decline or marginality, while, in the second case, the agglomeration is recent enough not to have many spaces that need to be reused.

(ii) Lobbying groups have emerged in many Italian cities in the construction and real estate markets. They have continuous opportunities to debate with public authorities through a structured process of governance. They take the form of sectorwise economic associations and exercise strong pressure on the public administration, not least because of the negative side effects generated by the new programming and planning tools requiring the participation of privatesector players. These forces sometimes operate to bring about economic deconcentration by favoring the construction of new shopping and leisure centers; other times, they bring about residential deconcentration by favoring the construction of new residential areas.

(iii) Of the planning and development tools cited earlier, PRUSST and Territorial Pacts have interesting indirect effects on deconcentration. These tools are not targeted to either land use regulation or planning. Their main aim is to allow sustainable local development through interventions related to infrastructure and firms operating in various sectors. The Italian government created these territorial programs in the second half of the 1990s as tools for de facto strongly economically oriented territorial development. Spatial organization is the consequence, not the cause, of such objectives. These instruments can, in fact, derogate from the regulations of City Master Plans and mainly affect peripheral areas, thereby contributing to determining the existence of deconcentration processes. If the creation of a new shopping center is decided 
as part of a PRUSST or a Territorial Pact, it is not a decision about land use and planning, but rather a decision about the development model of the concerned area. In this rationale, the creation of a shopping center implies the creation of additional job opportunities concentrated within the center, and the possibility of reducing prices in favor of territorial and extraterritorial residents. It is not a measure taken in order to decongest the town centre or reduce traffic or improve the quality of the environment. Indeed, the objectives of economic and employment development sometimes go against the aims of improving the quality of life and the environment.

(iv) Italian regions may use the law on retail commerce to implicitly decide about retail deconcentration. The law enables regions to establish how many new shopping centers can be created over a given period of time and select possible candidate areas. So in reality, they decide what the commercial poles of attraction will be, not what the city planning should be, the latter being only an implicit consequence. Moreover, with such plans, regions decide whether greater importance should be attributed to supermarkets and hypermarkets or to small neighborhood shops. Shop owner associations, which represent the interests of small traders, are very important in this debate; they exercise their contractual power in dealings with the region to oppose the progress of malls which, in their opinion, "kill" neighborhood retail.

(v) Agencies for ASI (Aree di Sviluppo Industriale, or Industrial Development Areas) are responsible for developing industrial areas within municipalities. ASI plans take precedence over City Master Plans and determine the organization of such areas. Given the particular structure of Italian cities, these are often periurban areas, and therefore the effective or ineffective action of the agencies has consequences for the creation - or the noncreation - of new industrial activities on the periphery of metropolitan areas. In this case too, the scope is not planning, but rather the economic and employment development of a particular area.

\section{Profile of Regional, Subregional, and Local Policies Relevant to Deconcentration in the Rome Metropolitan Area}

The Rome metropolitan area does not exist as an autonomous administrative entity. A debate about the need to replace the government of the City of Rome and its province with a metropolitan authority has been going on for decades. But the metropolitan region-as an administrative authority-has not yet been implemented. On 3 October 2010, Roma Capitale was set up as a kind of compromise. This local authority replaces the City of Rome while keeping its boundaries unchanged. Figure 1 indicates the area identified by the authors of this paper as the metropolitan region. The definition is based on the parameters identified by the SELMA project for a comparative multinational analysis.

The main tools of regional territorial government with indirect effects on deconcentration are the Regional Plan of Territorial Coordination and the law on retail commerce. The Latium region, where the Rome metropolitan area is located,
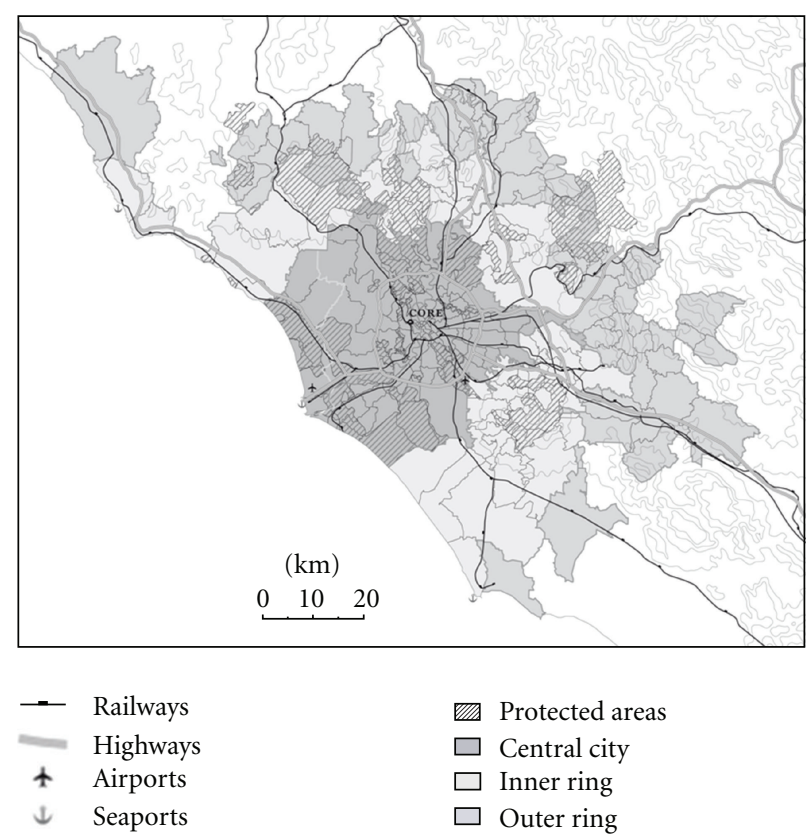

FIGURE 1: Rome metropolitan area. Source: own elaboration.

adopted the Regional Plan of Territorial Coordination in February 2001, after previously adopting a document with guidelines for local planning that did not, however, have the binding force of a law. The Latium region issued its law on retail commerce in 1999.

As these regulations were issued in the late 1990s, they had no effect on deconcentration in the period studied in this paper. They will probably have some effects, albeit minimal ones, in the coming years. These laws merely provide guidelines for the action of provinces and municipalities to which planning power is conferred. The guidelines can be summarized as follows: supporting firms in all sectors; attracting firms, particularly those working in the advanced services; protecting natural and cultural heritage; supporting local economic development; supporting the decentralization of public offices; improving the urban quality of settlements; improving the quality of public services; localizing shopping centers where roads and infrastructure exist; improving accessibility, using old, abandoned buildings as much as possible for new economic activities and harmonizing the various economic activities. Those guidelines are so general and short-lived that it will all depend on how they are received and applied at the provincial and municipal levels.

The main tools of subregional territorial government with indirect effects on deconcentration are the Provincial Plan of Territorial Coordination, Territorial Pacts, and PRUSST. The Territorial Plan of Provincial Coordination for the Province of Rome was adopted in 1998. In 2002, it was given a new name: the Provincial Master Plan. The Province of Rome had had no Plan previously, merely general guidelines for the actions of municipalities. The general aims are supporting balanced economic growth and favoring local development in the territory. The Provincial Plan aims to improve infrastructure and mobility, attract new firms, 
particularly in the advanced tertiary sector, improve the employment situation, and protect and enhance natural and cultural heritage. The entire provincial territory is given value and the potential of each local area highlighted. Considering the long period that will be required for the implementation of these guidelines, any possible effects on deconcentration will only appear in the coming years.

In the Rome metropolitan area, other subregional tools impact deconcentration: the Territorial Pact of Fiumicino; the Territorial Pact of Civitavecchia; the PRUSST for Fiumicino and the PRUSST for Civitavecchia. All of these were created in the late 1990s and have the power to derogate from regulations imposed by regional, provincial, and local Plans.

These plans and development projects are important for future deconcentration in the Rome metropolitan area, as they envisage strengthening the Fiumicino pole, where the airport is located, and the Civitavecchia pole with its port. In the case of Fiumicino, the Territorial Pact and PRUSST aim to create a strong tourism center around the archaeological and environmental resources using the town's proximity to Rome, a traditional tourist destination. Because of this strategy, plans and projects envisage a strengthening of the road and rail route connecting Fiumicino to Rome. This decision has already caused consequences in terms of deconcentration: in the past few years, many firms not operating in the tourist sector have decided to locate along this route. In the case of Civitavecchia, the Territorial Pact and PRUSST aim to enhance the status of the port, which has become Italy's leading cruise port in recent years, following the Holy Year 2000. These projects intend to highlight local environmental resources and monuments and develop the road and rail route connecting Civitavecchia to other cities, including Rome. It is foreseeable that these interventions will bring about future deconcentration along the route connecting Rome and Civitavecchia, as is already the case for Fiumicino.

The main tool of local territorial government is Rome's City Master Plan. The deconcentration process in the 1991 to 2001 period took place while Rome City Hall was still using the old City Master Plan approved in 1962. The new City Master Plan was approved in 2003 and has been in effect since 2008. In 1993, however, an important change in Italian legislation affected Rome's City Master Plan: the direct election of city mayors. One of the main effects of that law is that mayors are now directly responsible for implementing government programs. In fact, government programs are identified and largely oriented by mayors. Francesco Rutelli, Mayor of Rome from 1993 to 2000, started the process to create a new City Master Plan and introduced new planning elements such as the 1995 Posterplan, which outlined the administration's goals, and the 1997 Piano delle Certezze or Plan of Certainties, a series of changes and variations to the 1962 Master Plan that were necessary in the phase of transition to the new Plan. These two elements, which comprised the municipality's planning objectives, were implemented in the course of a long collaboration with all the stakeholders. The Plan of Certainties was primarily implemented in coordination with the economic stakeholders with a view to completing projects that had already been initiated.
There were, therefore, several overlapping tools in use in the period considered in this paper: the 1962 City Master Plan on the one hand and the Posterplan and the Plan of Certainties on the other. The former, a legacy of the past, continued to have the binding force of a law but had been substantially modified by all the changes that had taken place in the interim and by the implementation of Piani di settore (sector-specific plans) and Piani Particolareggiati (in-depth plans). The latter two contemporary plans were statements of intent providing the basis for the new Master Plan.

The 1962 Master Plan created a city whose principal characteristic, according to Maurizio Marcelloni, the coordinator of the new Master Plan, was that it was without rules, in that individual freedom and behavior prevail over the limits imposed by a social organization [19]. The 1962 Master Plan envisioned three main points: (i) breaking down the city's compact, monocentric structure by creating a road route and shifting the city centre eastwards to set up the SDO (Sistema Direzionale Orientale), or Eastern Office District, so as to clear the historical centre of tertiary activities; (ii) encouraging road travel and transport; (iii) expanding the city by building self-sufficient residential districts with a focus on functionality.

What has actually happened is that (i) services have not abandoned the city centre; rather, they have been strengthened and expanded, as the city centre and its cultural attractions of high quality are a major draw; (ii) the roads intended to increase road transport and travel have been only partially built and do not serve the residential buildings, which were not constructed in line with the Plan's recommendations; (iii) while self-sufficient residential districts have been developed, the problem is that although they are very efficient, with a good transport network in each district, they are not well connected to each other and the rest of the city.

The final result is a city that remains compact and monocentric, where the historical centre remains the most vibrant and attractive part, and a nonregulated and often degraded periphery with a uniquely residential function, poorly connected to the centre by an inefficient transport system. It is easy to understand why many observers agree that Rome is a city without rules. This statement also crops up regularly in political circles, where the objective of imposing rule and order on the city is continuously mooted. From this viewpoint, too, Rome reflects the overall image of Italy as a society in which the enforcement of a law is an exception rather than the rule and where the disorderly accumulation of laws makes it so difficult to enforce them that their very accumulation is an increasingly strong argument for nonenforcement [19].

The Posterplan and Plan of Certainties, as well as the new City Master Plan, start from the problems unsolved or generated by the 1962 Master Plan. While the new plans have no specific goals related to deconcentration, they prioritize the creation of new centers to generate a polycentric city. These new centers will be connected to both residences and businesses. The Rome municipality has selected the places with the most important infrastructures to house the key metropolitan functions: the new Centro Congressi or Conference Centre in the Eur district on the outer edge of the core, 
the Fiera di Roma trade fair grounds along the route connecting the rest of the city centre to Fiumicino and the airport, and the new Polo Tecnologico or technological pole along the Tiburtina road. The Rome municipality has also chosen to fill the urban empty spaces left over from uncontrolled and illegal building activity with green areas or new office districts.

\section{Economic Land Use Growth and Deconcentration in Rome}

Deconcentration is not acknowledged as a topic and therefore as a problem. In fact there is not even a precise translation for the word "deconcentration" in Italian, and therefore, we had to use four different words to describe the concept during our interviews of private-sector stakeholders and the local authorities. We always had to be careful to create a common "vocabulary" that would be shared by the entire group at the beginning of each interview or seminar.

However, it is not because there is no word for it that the phenomenon does not exist. It simply means that deconcentration is not seen as a planning and urban development issue, but rather as one of economic efficiency and effectiveness. Those aspects, together with social equity, the quality of the environment, and rational and balanced territorial development are considered per se. The result is often a disordered and disorganized territory in which some interventions contradict the previous ones, and others rule out new ones.

When it comes to the deconcentration of shopping centers, for example, the stakeholders involved (citizens, consumers, small traders in inner urban areas, large firms, local authorities and trade associations for various sectors) have divergent, interests including social equity, environmental quality, and quality of life. The problem is that there are both "dominant" and "subordinate" players. The "dominants" (public authorities, private firms, and trade associations) focus their attention on some effects of the new interventions: (i) effects on prices and, therefore, on the costs for consumers; (ii) deformation of competition for small traders; (iii) effects on employment; (iv) effects on business growth. In so doing, they neglect other important effects such as congestion, pollution, changes in social behavior, marginalization of weak social groups, urban disorder, and inefficiency.

As regards changes in social behavior, it has been found that residents and consumers in general use shopping centers not only to shop, but also as new places for social relationships and for leisure and entertainment. These new social habits bring about a change in the demand curve for consumer goods and its price elasticity. At the moment of buying, regular mall customers behave not so much as purchasers of goods as users of a pleasant environment of which shopping is only one aspect; the consumer therefore escapes the rules of traditional behavior.

The trend towards deconcentration and connected phenomena is so fast growing that it cannot be easily regulated using the existing tools. Sector-specific economic regulation has therefore been chosen in some cases. For example, in the retail commerce sector, it is not a planning law that has been applied but rather a law regulating the sector on the regional scale, following the economic rationale of production and sales and ignoring the spatial logic. Parameters such as competition and economic efficiency are considered; territorial planning derives from this as a residual policy that cannot take into consideration either the quality of environment or the quality of life. It can therefore be concluded that the priorities of regional and local policies are (i) economic and employment growth, (ii) attracting investment, and (iii) entrepreneurial dynamism.

The asymmetry created by the coexistence of mediumto-long term planning policies regulated by law (the City Master Plan is a law, not merely a planning act, and usually requires a long period of time to be formulated, discussed and implemented: in Rome's case, e.g., it has taken around forty years to adopt a new Plan) and short-term economic policies not regulated by law (economic policies can be drawn up and implemented in few months) have led to the introduction of new tools that can make exceptions to ordinary instruments of physical planning such as the City Master Plan. This confirms the dominance of economic interests above all the others. The effects on the environment and the quality of life are clearly not calculated or envisaged and are therefore unexpected.

Shopping complexes and entertainment centers are the most significant element of economic deconcentration, and their consequences can be summarized as follows: (i) control over the price of goods and, consequently, reduced costs for the end consumer; (ii) implicit and explicit control of inflation; (iii) changes in the land market: land is more expensive than it used to be when used for industrial settlements, but less expensive than it could be if used for residential purposes; (iv) changes in local retail competition: the presence of shopping centers induces a different dynamic for small traditional shops; (v) changes in consumer habits; (vi) a differently organized demand for goods and different time budgeting; (vii) marginalization of weak social groups (e.g., old people and households living under the poverty line), who find it hard to access shopping centers and have fewer and fewer neighborhood small shops available to them; (viii) a different spatial distribution of commercial and leisure activities; (ix) an increasingly mobile population; (x) overuse of the road system by cars and increased atmospheric pollution, because deconcentration is decided on the basis of economic rather than planning-related criteria; as a result, the locations of shopping and leisure centers do not correspond to the transport infrastructure.

The deconcentration phenomena studied here have mainly occurred as a result of the location choices of firms and public policies driven by economic reasons, rather than as a consequence of planning policies. While this has ensured high economic efficiency, it has encouraged imbalanced governance, with agreements between public authorities and private-sector firms prevailing over the general interest, and little transparency. Our interviews show that business and building trade associations have played an important role. The latter in particular appear to have played a major role 
in blocking or slowing down the brownfield market in some areas, and lobbying to steer the development of greenfield sites, pushing for the inclusion in City Master Plans of many residential areas that generate increased value and, therefore, increased land prices. A strong boost also seems to have come from the retail commerce sector, particularly associations representing small shops that oppose big box retailers. Hypermarkets, although important in the deconcentration process, therefore turn out to be underdimensioned with respect to the population.

The interviews also highlight the fact that environmental and consumer associations do not play a decisive role, with a few exceptions: in the Rome municipality, for example, environmental associations have played an important part in the fight against the construction of illegal buildings and for the creation of protected areas.

The actions of the various public stakeholders have suffered from a lack of coordination, as they have been implemented by different authorities at different levels of the hierarchy in different economic situations (recession or growth).

Some aspects of contemporary deconcentration are also the unexpected result of infrastructural and transport policies that were implemented many years ago. In the specific case of Rome, one of the driving forces of deconcentration has been the choice, made decades ago, of creating "gateways" to the metropolitan area through transport infrastructure such as motorway exits, airports, and ports.

\section{Conclusions}

This paper has discussed the subject of economic deconcentration and its relation to planning policies in the Rome metropolitan area. The possible connection between economic deconcentration and sprawl has been investigated in depth in the US but less extensively studied in Europe. The pattern of economic deconcentration in Rome is small-scale and scattered. The city centre continues to exert a strong power of attraction over firms, especially tertiary-sector firms. Rome's case fits in with the Mediterranean model of deconcentration, characterized by low levels of "effective" regulation. Italy has a complex regulatory system, but few laws are actually implemented. Urban planning is a very decentralized task, as Italy does not have national spatial planning, and is mainly implemented at the local level, where a great deal of attention is paid to infrastructure. In the period analyzed in our research, planning policies have been characterized by a largely bottom-up approach inspired by the principles of local development, and a number of new planning tools have been introduced by law. None of these planning tools and policies make any specific reference to deconcentration. Planning has only an indirect effect on deconcentration. Other policies relating to the industrial and retail commercial sectors also have indirect effects on deconcentration.

In the case of the Rome metropolitan area, the main tools of territorial government at regional level that might indirectly affect the deconcentration process are the Regional
Plan of Territorial Coordination and the law on retail commerce, but their effect would in any case be very limited. Their guidelines are so general and short-lived that it will all depend on how provinces and municipalities decide to implement them. At the subregional level, the main tools that could affect deconcentration are the Provincial Plan of Territorial Coordination, Territorial Pacts, and PRUSST, while, at the local level, the main tool is the City Master Plan.

The overlapping and simultaneous actions of all these planning tools have created a disordered and disorganized territory in which some interventions contradict the previous ones and others rule out new ones. Deconcentration has mainly taken place as a consequence of the location choices of firms and public policies driven by economic reasons rather than as a consequence of planning policies. While this has ensured high economic efficiency, it has favored imbalanced governance, with agreements between public authorities and private-sector firms prevailing over the general interest, and little transparency. The actions of the various public stakeholders have suffered from a lack of coordination, as they have been implemented by different authorities at different levels of the hierarchy in different economic situations (recession or growth). Some aspects of contemporary deconcentration are also the unexpected result of infrastructural and transport policies that were implemented many years ago. In Rome, economic deconcentration and the quality of life are not the focus of specific policies but rather the indirect consequences of economic policies with different objectives and the independent choices made by firms.

\section{Authors' Contribution}

While this paper is the result of a joint collaboration by its two authors, A. Montanari wrote Sections 1, 2, and 3, and B. Staniscia wrote all the other sections.

\section{Acknowledgments}

The research has been carried out within the framework of the SELMA project funded by the European Union under the "Energy, Environment and Sustainable Development" FP5 Programme (1998-2202), Key Action 4 "City of Tomorrow and Cultural Heritage" (contract no. EVK4-CT-200200102).

\section{References}

[1] P. S. Nivola, Laws of the Landscape, How Policies Shape Cities in Europe and America, Brooking Institution Press, Washigton, DC, USA, 1999.

[2] A. Borsdorf and H. Wimmer, "The European city: a phase-out model; challenges for European urban policy and research in the 21st century," in Proceedings of the Conference on the Role of Urban Research in the 7th Framework Programme, January 2005, http://www.mep.tno.nl/super/.

[3] A. Montanari and B. Staniscia, "Types of economic deconcentration in European urban space. Magnitude, physical form, sectoral composition and governance context," Die Erde, vol. 137, no. 1-2, pp. 135-153, 2006. 
[4] A. Montanari and B. Staniscia, "La deconcentration economica nello spazio urbano europeo. Il caso dell'area metropolitana Chieti-Pescara," Rivista Geografica Italiana, vol. 114, no. 2, pp. 207-234, 2007.

[5] A. Montanari, B. Staniscia, and S. Di Zio, "The Italian way to deconcentration. Rome: the appeal of the historic centre, Chieti-Pescara: the strength of the periphery," in Employment Deconcentration in European Metropolitan Areas. Market Forces Versus Planning Regulations, E. Razin, M. Dijst, and C. Vazquez, Eds., pp. 145-178, Springer, Dordrecht, The Netherlands, 2007.

[6] E. Razin, "Introduction: deconcentration of economic activities within metropolitan regions: a qualitative framework for cross-national comparison," in Employment Deconcentration in European Metropolitan Areas. Market Forces Versus Planning Regulations, E. Razin, M. Dijst, and C. Vazquez, Eds., pp. 1-27, Springer, Dordrecht, The Netherlands, 2007.

[7] J. N. Larsen, Governance, Policy and Determinants of Economic Land Use Deconcentration, Danish Building Research Institute, Copenhagen, Denmark, 2005.

[8] M. Dijst and C. Vazquez, "Employment deconcentration in European metropolitan areas: a comprehensive comparison and policy implications," in Employment Deconcentration in European Metropolitan Areas. Market Forces Versus Planning Regulations, E. Razin, M. Dijst, and C. Vazquez, Eds., pp. 265291, Springer, Dordrecht, The Netherlands, 2007.

[9] G. Nuvolati, "Urban development programmes in Italy. The UGIS project for analyse the effects of the URBAN community initiative," in Proceedings of the Eura Conference Urban and Spatial European Policies: Levels of Territorial Government, pp. 18-20, Turin, Italy, April 2002.

[10] A. Faludi and B. Waterhout, The Making of the European Spatial Development Perspective. No Masterplan, Routledge, London, UK, 2002.

[11] Commission of the European Communities, The EU Compendium of Spatial Planning Systems and Policies: Italy, Commission of the European Communities, Brussels, Belgium, 2000.

[12] B. Staniscia, L'Europa dello sviluppo locale. I Patti Territoriali per l'Occupazione in una prospettiva comparata, Donzelli, Roma, Italy, 2003.

[13] G. Cinà (a cura di), Pianificazione e sviluppo locale. Un profilo della esperienza italiana, L'Harmattan Italia, Torino, Italy, 1997.

[14] F. Governa and C. Salone, "Territories in action, territories for action: the territorial dimension of Italian local development policies," International Journal of Urban and Regional Research, vol. 28, no. 4, pp. 796-818, 2004.

[15] F. Governa and C. Salone, "Italy and European spatial policies: polycentrism, urban networks and local innovation practices," European Planning Studies, vol. 13, no. 2, pp. 265-283, 2005.

[16] P. C. Palermo, "Urban Italia: programma compiuto, progetto generativo," in Il programma Urban e l'innovazione delle politiche urbane. Il senso dell'esperienza: interpretazioni e proposte, P. C. Palermo (a cura di), Ed., pp. 13-18, Franco Angeli/Diap, Milano, Italy, 2002.

[17] U. J. Rivolin, "Shaping European spatial planning: how Italy's experience can contribute," Town Planning Review, vol. 74, no. 1, pp. 51-76, 2003.

[18] F. Governa and C. Salone, "Descrivere la governance. Conoscenza geografica e modelli di azione collettiva nelle politiche urbane e territoriali," Bollettino della Società Geografica Italiana, vol. 7, no. 1, pp. 29-50, 2002.
[19] M. Marcelloni, Pensare la città contemporanea. Il nuovo piano regolatore di Roma, Laterza, Roma, Italy, 2003. 


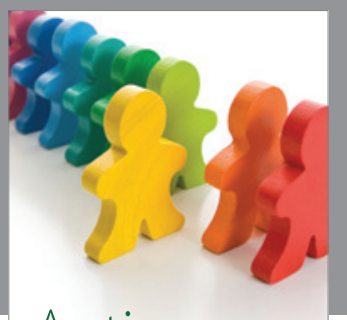

Autism

Research and Treatment
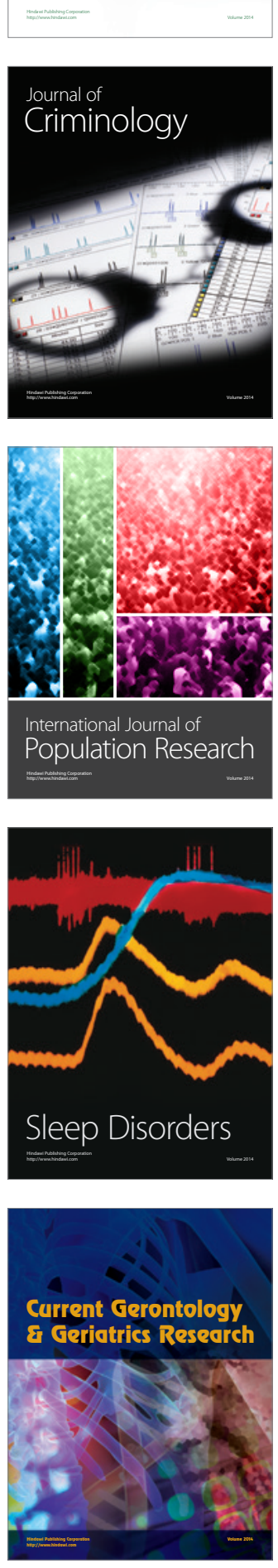
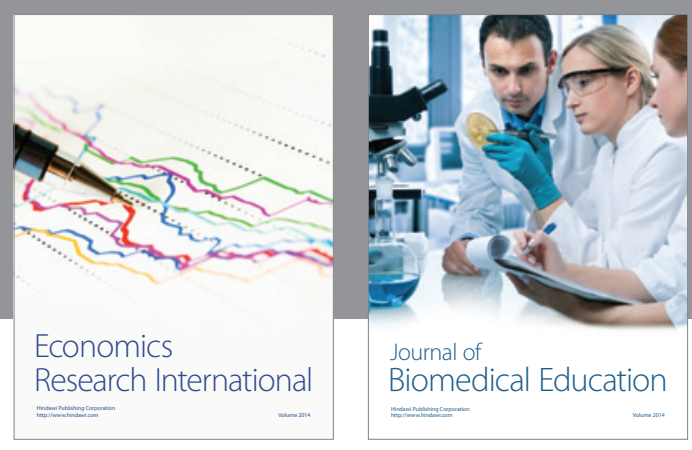

Journal of

Biomedical Education

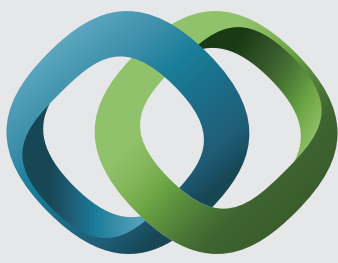

\section{Hindawi}

Submit your manuscripts at

http://www.hindawi.com
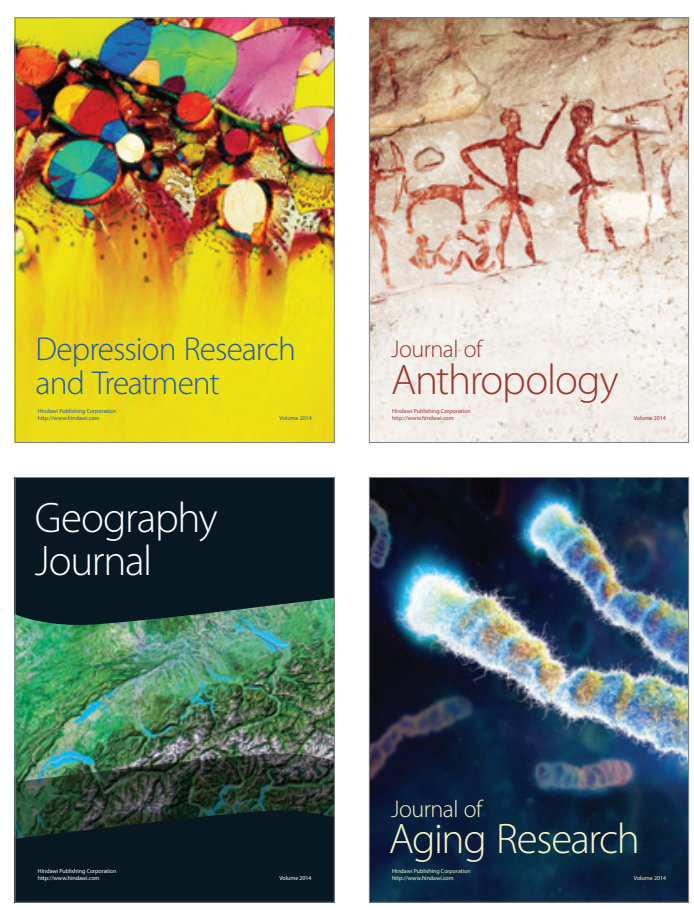

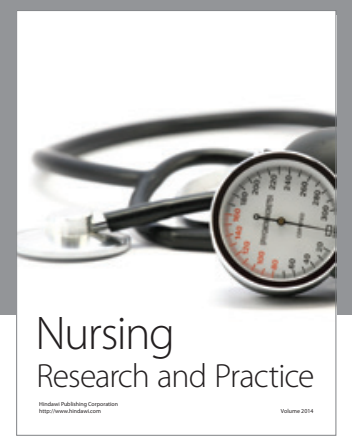

Nursing

Research and Practice

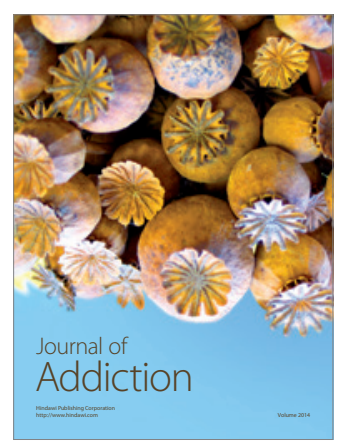

Child Development

Research

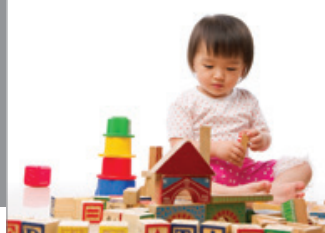

迥
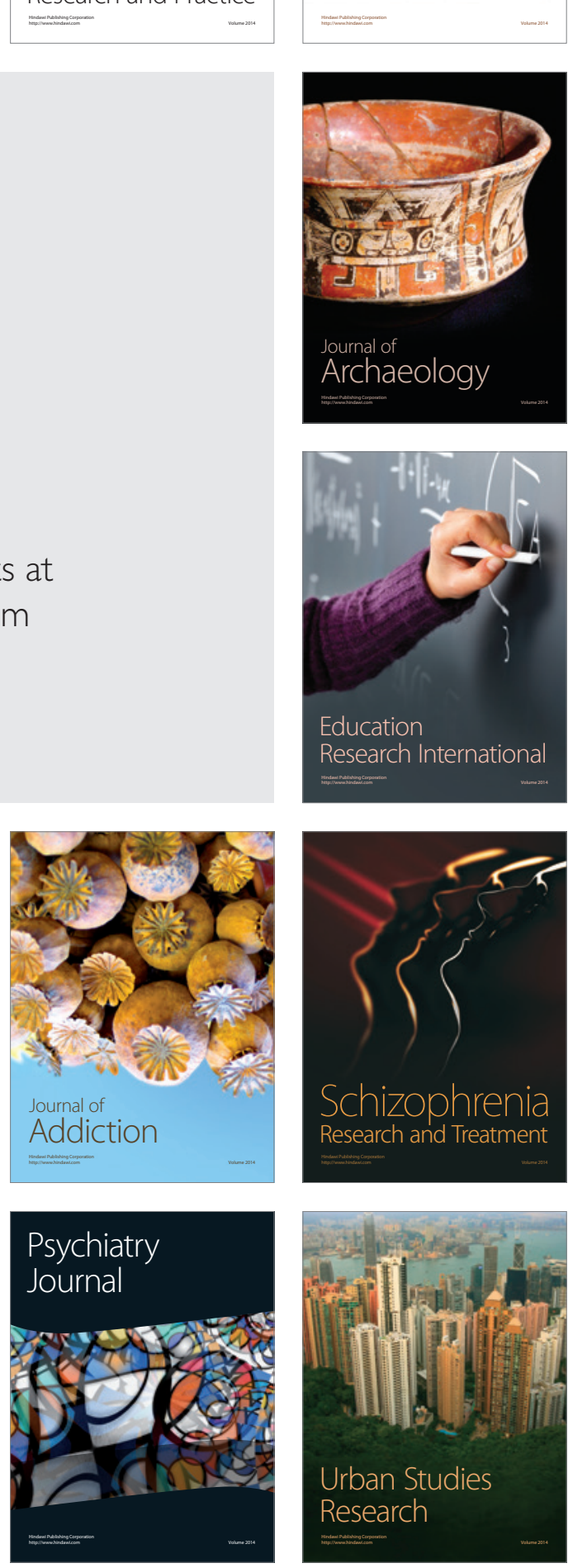